\title{
THE ROBOTIC MAN BY HABIT: AN EXISTENTIAL ANALYSIS OF ALBERT CAMUS' THE MISUNDERSTANDING
}

\author{
Mukundwe Siame \\ University of Zambia \\ mukundwesiame@gmail.com
}

\begin{abstract}
Human existence is essentially characterised by habit. It is habit that carries us most of the times, from one day to another as our daily activities are mostly routine in nature. As Albert Camus (1942) notes, most of our daily activities are commanded by habit. This is why Camus compares the human condition to that of Sisyphus. Camus submits that like Sisyphus, the same rhythm carries us from one day to another and this makes our actions automatic, if not robotic. Furthermore, Camus notes that habit usually leads to monotony, boredom and meaninglessness of our actions. This is what he refers to as the absurdity of human existence; a feeling of futility we may experience when we become aware of the repetitiveness of our routines and rituals (Craig, 2005); grosso modo, a lack of fundamental meaning in life. In this paper, our analysis of Camus' play, 'The Misunderstanding' (1943) is hinged upon Sartre's existentialism, which has close affinities with Camus' philosophical concept of the absurd. In 'Being and Nothingness' (1943), Sartre submits that the problem of being is the most important phenomenological problem. According to Sartre, there are essentially, two modes of existence; Being-in-itself and Being-for-itself. Being-in-itself is the type of being that objects in this world have; for example, Being-foritself is the being of human beings. In this article, we have submitted that habit robotises the characters in Camus' play in that it (habit) transforms them into Being-in-itself whose existence is passive and absurd.
\end{abstract}

Keywords: Habit, Absurd, Robot, Being-in-itself, Bering-for-itself, existentialism, Sartre, Choice

\section{Introduction}

Existentialism, as its name suggests, is centred on the question of existence. The term is often used in a general way to refer to a number of authors of the nineteenth and twentieth century whose thought focused on the concrete lived experience of an individual in the world. Hence, existentialism emphasises the importance of the individual man living his own life. Existentialism was characterised by a reaction against traditional philosophy which tended to focus on what is common in all human beings. As Craig (2005: 252) points out: 
Existentialism arose as a backlash against philosophical and scientific systems that treat all participants, including humans, as members of a genus or instances of universal laws. It claims that our existence as unique individuals cannot be grasped adequately in such theories, and that systems of this sort conceal from us the highly personal task of trying to achieve self-fulfilment in our lives.

Consequently, existentialists reject systems that tend to propose answers (answers that apply to all human beings) to the questions of meaning and purpose in life. Allencompassing systems do not take into account what it is like to be human, and are, therefore, detrimental to an individual's development as an authentic human being. Furthermore, Sreekumar (2014) submits that existentialism does not seek to understand man in terms of some fundamental rational concepts like what was advocated by Plato, Descartes, Kant or Hegel. It focuses on the individual; his concrete lived experience; his anxiety, his worries, his problems. Because each individual's lived experience is unique, the ideas of universalism, absolutism and abstract theorisation are rejected.

It is very difficult to come up with a definition of the term existentialism because thinkers regarded as existentialists differ considerably in their views about human existence. For instance, among existentialists, you have theistic and atheistic existentialists. For theistic existentialists, such as Soren Kierkegaard, Gabriel Marcel and Karl Jaspers, God exists and man's relationship with God is an important philosophical problem. Kierkegaard proposed the concept 'leap of faith' that would bring an individual to a close relationship with God. For atheistic existentialists, such as Friedrich Nietzsche, Jean-Paul Sartre and Martin Heidegger, God does not exist. Nietzsche even proclaimed that 'God is dead' and that it is up to man to forge meaning to his life before he fades away into nothingness. It is these widely different views held by thinkers considered as existentialists that make it difficult to define the term existentialism. As a matter of fact, most of the authors regarded as existentialists rejected the label and did not want to be associated with it. Heidegger, for instance, refused to be associated with existentialism, and so did Camus. However, the only philosopher who claimed himself as an existentialist was Jean-Paul Sartre. He even presented a paper, which was later published as a book, entitled Existentialism is a Humanism, in which he defends existentialism against its critics.

Despite these differences in their evaluations of the human condition, existentialists have a number of common themes in their writings. Firstly, all existentialists share Sartre's famous dictum 'existence precedes essence.' This means that 'humans have no pre-given purpose or essence laid out for them by God or nature' (Craig, 2005:253). Furthermore, Sartre (1946:3) explains that 'man first of all exists, encounters himself, surges up in the world and defines himself afterwards.' Since there is no pre-given essence, it is up to each one of us to decide what kind of person we would like to be through our choices and actions. We create ourselves through our choices and actions; man makes his essence through his actions and choices as he lives. 
The dictum 'existence precedes essence' entails, therefore, that we are responsible for the person we become. We have to take responsibility of how our life has turned out and not put the blame on others. Of course, there are social and biological factors to be considered as we create ourselves. Our relationships with others may influence the person that we become. However, these are not determining factors but mere influences, that is, it is not automatic that when one finds himself/herself in a particular social situation, one will act in a certain way. As humans, we have the ability to reflect on these factors and choose how to respond to the situations we encounter. The concept of freedom is important to existentialists. As Sartre asserts, 'man is condemned to be free.' It is because we have freedom to choose that is why we are responsible for the person we become. Because of the responsibility it entails, freedom brings about the feeling of anguish.

In a nutshell, existentialism is not a philosophical school because thinkers associated with the movement have diverse views and it is hard to isolate common doctrines in their writings. A common theme that all existentialists share is their focus; emphasis on man as he lives in the world. Existentialism emphasises individuality and observes that each individual encounters their existence differently. As mentioned earlier, most writers who were considered existentialists refused the label. Solomon (2000) observes that Sartre was the only philosopher who used the term existentialism to refer to his own work during and immediately after the Second World War. Hence, when we talk about existentialism today, Sartre always comes to mind because he consciously associated himself to the movement and contributed greatly to the prominence of existentialism in the twentieth century. In this article, we will analyse Albert Camus' play The Misunderstanding from an existential point of view. Our analysis will be based on Sartre's theory of being, specifically, on his concept of two modes of being, namely; Being-in-itself and Being-for-itself.

\section{Being-in-itself and Being-for-itself}

In his magnum opus, Being and Nothingness (1943), Sartre asserts that the problem of being is the most important phenomenological problem. He presents his theory of being and submits that there are basically two modes of existence, namely; Being-in-itself and Being-for-itself. Being-in-itself is the type of being that objects in this world have, for example, a computer. They are fixed, rigid and cannot change. Furthermore, Sreekumar (2014) adds that they have no awareness of value of themselves since they do not have consciousness. 'The en-soi (Being-in-itself) signifies all objects around man. They are impermeable and dense, silent and dead. From them comes no meaning, they only are.' (Breisach, 1962: 97) In addition, Sartre uses the term 'in-itself' to refer to something that is self-contained, something that is complete (Spade, 1996). In Existentialism is a Humanism (1946), Sartre gives an analogy of the paper-knife in his attempt to describe being-in-itself:

If one considers an article of manufacture as, for example, a book or a paperknife, one sees that it has been made by an artisan who had a conception of it; and he has paid attention, equally, to the conception of a paper-knife and to the pre-existent technique of production which is a part of the conception... 
Thus, the paper-knife is at the same time an article producible in a certain manner and one which, on the other hand, serves a definite purpose, for one cannot suppose that a man would produce a paper knife without knowing what it is for.

The paper-knife, which represents being-in-itself, is an artefact designed by someone, and its design or blueprint sets limits to what it is and what it can do. Therefore, it is this design that gives the paper-knife its essence. The essence exists in the mind of the designer of the paper-knife before it can be produced, 'for one cannot suppose that a man would produce a paper-knife without knowing what it is for.' Hence, essence precedes existence for the paper-knife, as well as any other object designed in accordance with a plan in this way. In a further explanation of the being-in-itself, Spade (1996) points out that the in-itself violates the 'Principle of Sufficient Reason,' a controversial philosophical principle, which states that everything must have a reason or an explanation; that there must be some reason why things have turned out the way they have, and not some other way. Being-in-itself has no explanation, that is, there is no sufficient reason for its existence; it is contingent.

As for the Being-for-itself, Sartre uses this term to refer to the being of human beings. The for-itself is aware of its existence and its consciousness of its own existence is central to its being. In Existentialism is a Humanism (1946), Sartre submits that for the beingfor-itself, existence precedes essence. This means that the for-itself has no definition or essence given to it in advance. The for-itself defines and creates itself in the process of living. Man (for-itself) creates his own essence and gives meaning to his own existence through the choices he makes. This differentiates man from an object.

The future is very important for the for-itself because it forms part of its existence. Man is always projecting himself into the future. Sartre, as quoted by Daigle (2010), submits the following concerning the future of the for-itself:

Sartre says that the for-itself is a project; it is constantly making itself. Being a nothingness and a nihilating being, the for-itself is not determined, and hence, it is free to become through its actions. It can freely break from its past or even from its social or historical conditioning, and affirm itself through its actions (Daigle, 2010: 35).

Sartre points out that there is some kind of ambiguity, confusion about human existence because man is both an in-itself and a for-itself. Man is an in-itself in the sense that there is some element of facticity in his existence, meaning that there are things about man that he cannot change, things that are fixed; for instance, where I was born, my physical features (skin colour, height), my linguistic community, my past among other things. However, we transcend our facticity through our choices and actions. We are always more than our situation and what I am now need not necessarily reflect what I will be tomorrow (Skreekumar, 2014). Man's essence cannot be locked up in the past because it is always moving, dynamic; it is a becoming process. Hence, unlike other objects, man's being is not complete. A book is a book; it cannot become anything else. This kind of completion is not found in man. 


\section{Habit in Albert Camus' The Misunderstanding}

The Misunderstanding is a three-act play written by the French philosopher Albert Camus. The play, together with another play Caligula, the novel The Stranger and the essay The Myth of Sisyphus, forms what is referred to as the 'cycle of the absurd' in Camus's work. The play looks at the 'dark' side of the absurd. The character Jan who, after his peregrinations in life, returns home to his mother and his sister, Martha. The two women run a lodge as a means of livelihood, but they have been leading a very miserable life as the lodge does not attract a lot of customers. Hence, in order to escape from poverty, the two women have resorted to butchering every lodger and taking away their possessions. They drug their victims, and in their comatose state, throw them into a nearby river to drown. They have developed the habit of slaughtering every traveller who visits their lodge. With regard to habit, the mother informs her daughter Martha '...habit begins with the second crime. Just as something else ends with the first. The occasions may have been few and far between, but habit gains its strength from time... Habit made me answer him, and habit kept me from looking at him closely...' (5).

The two women justify their crime by saying that living is a burden, that it is more painful to be alive than to be dead. As Reck (1961:49) observes, 'the two women justify their habit of murder in much the same way that Caligula legitimises his limitless exercise of power: life is more cruel than they are.' Hence, Martha's words, 'we are kinder than life' (p.5). They make it seem as though they are doing a favour to their victims. Furthermore, the mother envies the condition of the dead when she says, 'His mind is at rest, free from decisions, free from all cares... He's shaken off the cross of life... No more obligations and nothing more to do. Oh, how I envy him!'(36).

When Jan returns home after being away for more than ten years, he does not reveal his identity. He wants to first observe the way they have been living and then surprise them by offering them the fortune he has amassed while away. However, his wife, Maria, insists that he reveals his identity:

But why not tell them you were coming? There's a case to be made for conventional behaviour, at certain times. If you wanted to be recognised, you couldn't have done better than to introduce yourself.... If you start out pretending to be something you're not, you'll end up in a mess. How on earth can you expect to receive more of a welcome than any passing stranger when you act just like one? (8).

Jan does not heed his wife's advice and he insists on spending a night with his mother and sister. He lodges his wife in another place so that he can carefully observe how his people have been living, 'see them, as it were, a little from the outside.' Naturally, he does not see any danger in spending a night under the same roof as his mother and sister, and he assures his wife, 'Remember, it's my sister and my mother that we are talking about. There can't be much to frighten you in that' (12).

Martha has a dream of leaving the lodge and all the suffering behind, and it is through murder that she is determined to realise this dream: 
Oh mother, mother! All we need is money! With money in our hands, there's an end to grey skies and damp, dripping roofs! We'll put the boardinghouse behind us and leave this town for good. And in their place, we'll have the open sea before us, the sea I have dreamed of for so many years!... We'll need a lot of money if we are to live by the sea.... we must give this man who's coming here our closest attention. If he has money on him, and plenty of it, then my freedom may begin with him (4).

Consequently, through the act of murder, the two women wish to acquire their happiness and freedom. Each traveller who comes to their lodge has to suffer the safe fate, and according to Martha, 'a room like this is made for sleeping in, and a world like this for dying.' Habit blinds them from recognising their son, their brother, and they begin to plot Jan's death:

Martha: He has to die, mother

Mother: Yes. He has to die. Of course he does (5).

The mother repeatedly expresses some hesitation and tries to break free of the habit they are in, '... Let's not go through with it, not tonight at any rate.... Let's have a breathing space. Give him another day. You never know, he might be the means to our salvation' (23). However, Martha who is really determined to realise her dream informs the mother that their salvation lies in action. Hence, Jan suffers the same fate as every traveller who has visited their lodge. He becomes the latest victim of their gruesome act which has become automatic, robotic. He is butchered by his own mother and sister. The play can, therefore, be considered as an inverted story of the parable of the prodigal son. Instead of being welcomed and pampered, after being away for so long, Jan is butchered by his own mother and sister.

When Jan's identity is revealed, the mother realises the absurdity of her action and decides to commit suicide. According to her, 'when a mother fails to know her son, her function in this life has come to an end' (40). As for Martha, she does not show any emotion and expresses no remorse. In fact, she informs her mother that if she had known who Jan was, it would not have made any difference and she earlier points out that 'a son who came in here would be assured of the same treatment as any other guest...' (19). Maria is shocked by Martha's demeanour after she reveals that her and her mother have killed Jan. She talks calmly and shows no regret, as if nothing serious has happened, 'You stand there as cold as ice, talking calmly of something that should make you want to run out into the street, screaming like an animal in pain!' (47).

In this play, habit has transformed the two women into Being-in-itself, whose existence is passive and absurd. Their actions have become robotic in the sense that they are more like robots designed for a specific purpose, and that is to kill every traveller who visit their lodge. The mother realises the robotic aspect of her actions when she says, 'I kept going. That's true. But it was only out of habit. Like a living dead'(41). Reck (1961: 49) argues that 'for the mother, grief at recognising she has killed her own son succeeds in changing habit into consciousness, and she joins him in death.' 
It has to be noted that the characters in Camus' play are used to convey the author's existentialist ideas. It is for this reason that Behrens (1964) refers to them as 'CharacterIdeas' because they serve as 'an embodiment of some aspect of Camus' thought.' One of the characters that attracts our interest in this regard, and who serves as a mouthpiece of Camus' philosophy is Martha. She is so determined to achieve her dream of living by the seashore no matter the cost. Behrens (1964) observes that she is the incarnation of Camus' philosophical concept of révolte. She considers her mother's suicide as a betrayal because she will never be able to achieve her dream. The only love which she has known her entire life is taken away from her, and this shatters her completely. She does not express any remorse over what has happened, and when Maria, her sister-in-law, confronts her, she addresses her in a very cold manner. Her outlook on life is encapsulated in her last words to Maria:

I owe you something. I killed him. You have a god. Pray to him. Ask him to turn you into stone. It's the only true happiness. And he knows it. That's why he keeps it for himself. So do what he does. Turn yourself into stone. Be deaf to all cries (50).

According to Martha, the world we live in is one where God is indifferent to man's cries and the best thing one could do is to become like a stone so that one could not feel the horrors of the world.

When Maria prays for help, an old man appears. The character of the Old Man is a bit strange in the sense that he does not say or do anything. When Jan encounters the old man for the first time, he has the impression that he does not hear a thing you say. Like Meursault, in Camus' novel The Stranger, the Old Man is completely detached from life and exhibits a total indifference to people. When he appears after Maria's prayer, he, for the first time speaks and asks her if she was calling for him. When Maria asks for his help, his answer is 'No' and the play ends.

The philosophical idea of the absence or indifference of God permeates existential literature and this idea was reinforced by Nietzsche when he proclaimed 'God is dead,' hence, the character of the old man in this play who is indifferent to Maria's cry and refuses to help her. This absence of a supreme being who is supposed to watch over man runs throughout Camus's work. Man is depicted as abandoned, and left to look out for himself.

\section{Conclusion}

In conclusion, our analysis of Camus's play The Misunderstanding was based on Sartre's existentialism, particularly his distinction between two modes of being, namely; Beingin-itself and Being-for-itself. It was established that being-in-itself refers to the being that objects in this world have. They are fixed, self contained and complete. Furthermore, they have no awareness of themselves since they do not have consciousness. Being-for-itself, on the other hand, refers to being of human beings. Human beings are aware of their existence and their consciousness is central to their being. In the play under consideration, 
it was established that the habit of killing developed by Martha and the mother transforms them into being-in-itself, whose existence is passive and absurd. They exist to kill every traveller who visit their lodge. Habit has taken root in their lives that they fail to recognise their brother, their son when he returns home after being away for a long time. They treat him like any other traveller and he becomes their latest victim. Furthermore, the characters in this play are more like mouthpieces of Camus' philosophy in that they are used to convey the author's philosophical ideas.

\section{References}

Behren, S. (1964). 'Existential “Character-Ideas' in Camus' The Misunderstanding', Modern Drama, Vol. 7, No. 2, pp.210-212, doi:10.1353/mdr.1964.0009.

Breisach, E. (1962). Introduction to Modern Existentialism, Grove Press Inc: New York.

Camus, A. (1943). The Misunderstanding, Trans. G. Ley, Gallimard: Paris.

Craig, E.(2005). The Shorter Routledge Encyclopedia of Philosophy, Routledge: New York.

Daigle, C. (2010). Jean-Paul Sartre, Routledge: New York.

Reck, R. (1961). 'The Theater of Albert Camus,' Modern Drama. Vol. 4, No. 1, pp.42-53, doi:10.3138/md.4.1.42.

Sartre, J.P. (1946). Existentialism is a Humanism, Trans. P. Mairet, Gallimard: Paris.

Skreekumar, N. (2015). Existentialism: Main Features; Existence Precedes Essence; Freedom and Responsibility. [YouTube video] Available at: https://www.youtube.com/ watch? $\mathrm{v}=\mathrm{oL} 4 \mathrm{skuHK}-9 \mathrm{w}$ [Accessed 5 February 2019]

Solomon, R. (2000). No Excuses: Existentialism and the Meaning of Life. The Great Courses, Corporate Headquarters: Virginia.

Spade, P.V. (1996). Jean-Paul Sartre's Being and Nothingness, Class Lecture Notes, Indiana University. 